\title{
Prospects of Rural Areas Development in South of Tyumen Region
}

\author{
Pavlova Larisa Leonidovna \\ Department of Marketing and Municipal Management of \\ Tyumen Industrial University \\ Tyumen Industrial University \\ Tyumen, Russia \\ pavlova68@yandex.ru
}

\author{
Kolesnik Elena Andreevna \\ Department of Marketing and Municipal Management of \\ Tyumen Industrial University \\ Tyumen Industrial University \\ Tyumen, Russia \\ eakolesnik-10@mail.ru
}

\author{
Filatova Elena Leonidovna \\ Leading economist (acting head) of the planning and economic department \\ Federal State Budgetary Educational \\ Institution of Higher Education \\ «Northern Trans-Ural State Agricultural University» \\ Tyumen, Russia \\ el.filatova@yahoo.com
}

\begin{abstract}
The article gives an estimate of the social-economic situation in the south of Tyumen region, which has pointed to the crisis in the agricultural sector. In this regard, the authors have developed approaches to the development of rural areas in the south of the region to provide the population with food products, forming the scientific novelty, the practical significance of this study and the prospects for further development of the topic. They are: 1. development of food products import from the nearby regions of the Russian Federation; 2. development of the regional agricultural production. The first approach is based on strong, long-established commodity relations between the subjects of the Russian Federation. However, in this case, the solution of problems related to the provision of food to the population will lead to aggravation of social problems related to employment of the population, primarily rural settlements of the region south. The lack of jobs in rural areas will lead to even greater outflow of the population to major cities. The second approach allows avoiding negative consequences, but requires a larger financial investment. This is due to the creation of new enterprises (reconstruction and modernization of old enterprises) (according to the regional program quite a large investment is allocated in this area) with the involvement of educational institutions in the cluster to create an interconnected and mutually reinforcing the "production - processing implementation of the finished product" cycle with scientificmethodical and consulting support of the process.
\end{abstract}

Keywords - rural area, food security, condition, prospects, development, reduction, decline.

\section{INTRODUCTION}

Agriculture is an important sector of the economy, aimed at maintaining the life support system of the population of the state, its food and national security, which is becoming more important and relevant in the context of the sanctions policy of the West. At the same time, the current situation in most rural areas of Russia is characterized by unfavorable development conditions with signs of socio-economic depression - the Russian village is currently experiencing socio-demographic, educational, cultural and economic crises. That is why, for the Russian state, the priority directions of agricultural economic policy are, firstly, the creation of conditions that ensure the sustainable development of rural areas, secondly - the increase in agricultural production, and thirdly - the increase in the competitiveness of domestic agricultural enterprises. At the same time, the functioning and development of agricultural production to meet the food needs of the regions serve as a guarantee of food security of the country [5,7], and it is also the basis for the formation of effective competitive production in the region and the driving force of growth for industrial production in Russia. Thus, the study of the development of rural areas on the example of the Tyumen region south, its features and prospects, becomes relevant.

The aim is to study the peculiarities of rural areas functioning by the example of the south of Tyumen region and to assess the prospects for their development. The objectives are to estimate the socio-economic situation of the territories in the south of Tyumen region and formulate approaches to 
the development of rural areas of the region and provide the population with food products.

Tyumen region occupies a key position in the country's economy due to the powerful oil and gas cluster in the North of the region - on KHMAO and YANAO territories. The south of Tyumen region mainly an agricultural focus in the economy. The scientific significance and novelty of the work lie in the development of the indicator-maps of the economy of the territories in the regional south and the formation of directions of economic development in agriculture.

Theoretical and practical issues of rural areas development serve as a sphere of scientific interest of many Russian and foreign researchers. The various aspects of the functioning and development of rural areas (Bautin V.M., Los V.A., Bossel H., Mazunina M.V. et al.), problematic issues of agribusiness management (Ansoff I., Abalkin L.I., Glazyev S.Y., Granberg A. G. et al.), complex transformation (Lysochenko A.A.) and state regulation of rural areas development (Primak L.V., Petrov A.A. et al.) became the subject of the discussion. At the same time, the prospects for the development of rural areas in the regional context remain insufficiently studied.

\section{RESULTS AND DISCUSSION}

The role and importance of rural areas at the present stage of development of the Russian Federation are defined in the Concept of sustainable development of rural areas of the Russian Federation for the period up to 2020 [1], consisting in the performance of their most important national functions (industrial, demographic, labor, social, etc.), which are an important condition for successful socio-economic development of the state. Also, the rural areas of the country "have a powerful natural, demographic, economic, historical and cultural potential" [1], which, under the condition of rational use are capable of "ensuring sustainable multisectoral development, full employment, high level and quality of life" [1] directly for the rural population and ensuring food security of the country as a whole through the production of food resources by domestic agricultural enterprises in amounts sufficient to ensure the normal functioning of its population $[2,8]$.
Next, let us consider the features of rural development by the example of the south of Tyumen region.

The economy of Tyumen region has a territorial specialization: industrial centers of the North region (oil and gas cluster) are concentrated in Autonomous districts-KhantyMansiysk Autonomous Okrug-Yugra and Yamalo-Nenets Autonomous Okrug [1]. The main specialization of the Tyumen region south is agriculture, occupying about 2909.8 thousand hectares (or $85 \%$ ) of the entire region. The presence of soils with high fertility potential and relatively moderate climatic conditions enable to grow grains and legumes, vegetables, berries, and fodder for livestock development.

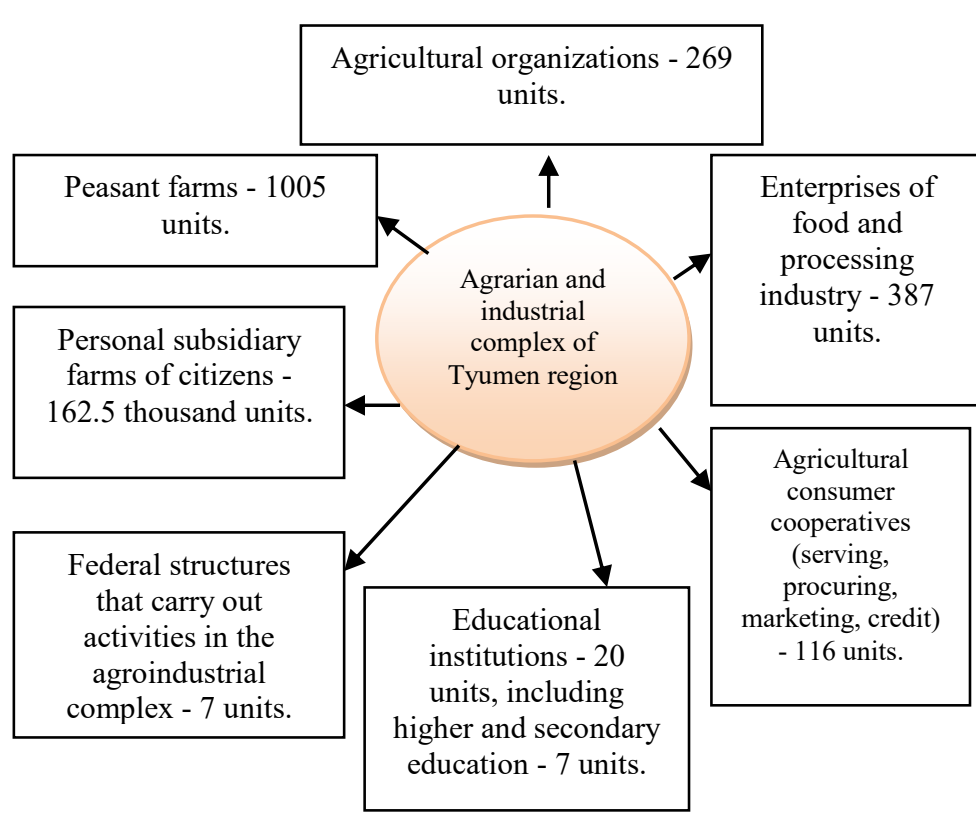

Fig. 1. System of agrarian and industrial complex of Tyumen region

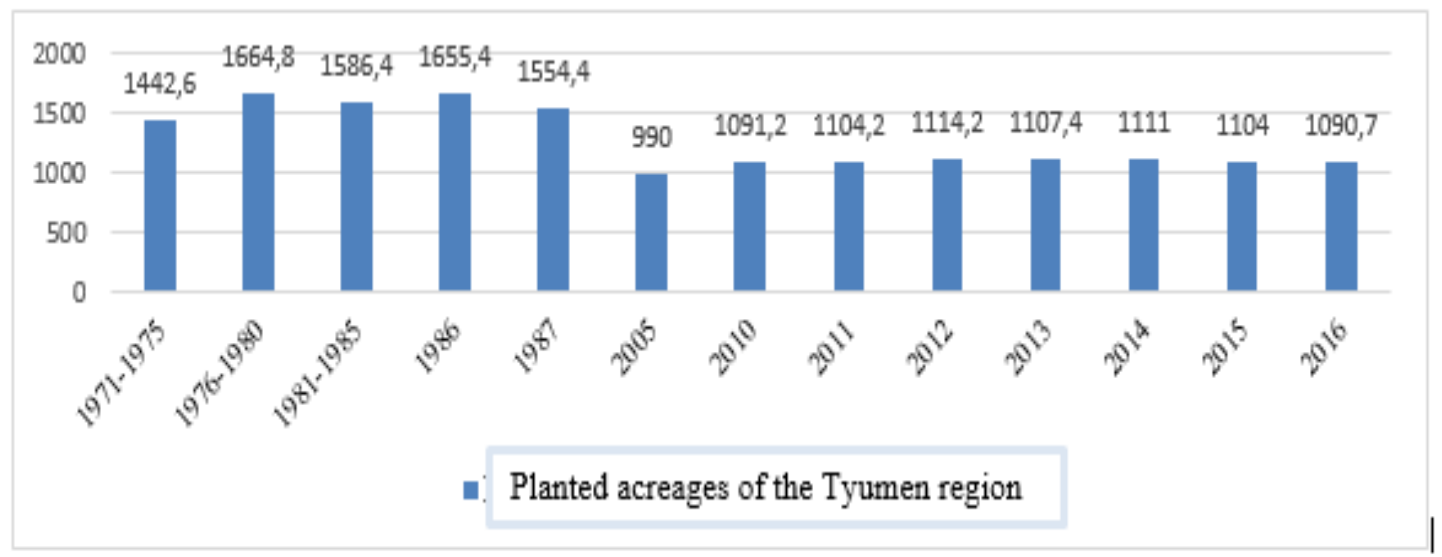

Fig. 2. Planted acreages of agricultural crops in Tyumen region (in all categories of farms), thousand hectares in 1971-2016 [6, 9] 
Let us assume that over the past few years there has been a reduction in planted acreages in farms of the region in all categories, as evidenced by the data in figure 1

The economic potential of Tyumen region is significant [3, 4,101 . Thus, in 2017, the index of industrial production in Tyumen region without Autonomous districts amounted to $102.6 \%$ with $101.0 \%$ in the Russian Federation. The region ranks first in terms of industrial production in both Russia and the Urals Federal district. The region's contribution to Russia's GDP is 3-6 times higher than that of other regions of the country (except Moscow). At the same time, the share of Tyumen region in the volume of agricultural production in Russia is $1.3 \%$ ( $28^{\text {th }}$ place) with $1.7 \%$ in 2015 , occupying $22^{\text {nd }}$ place); the share of agriculture (hereinafter - agribusiness) in the region's GDP is $5.4 \%$.

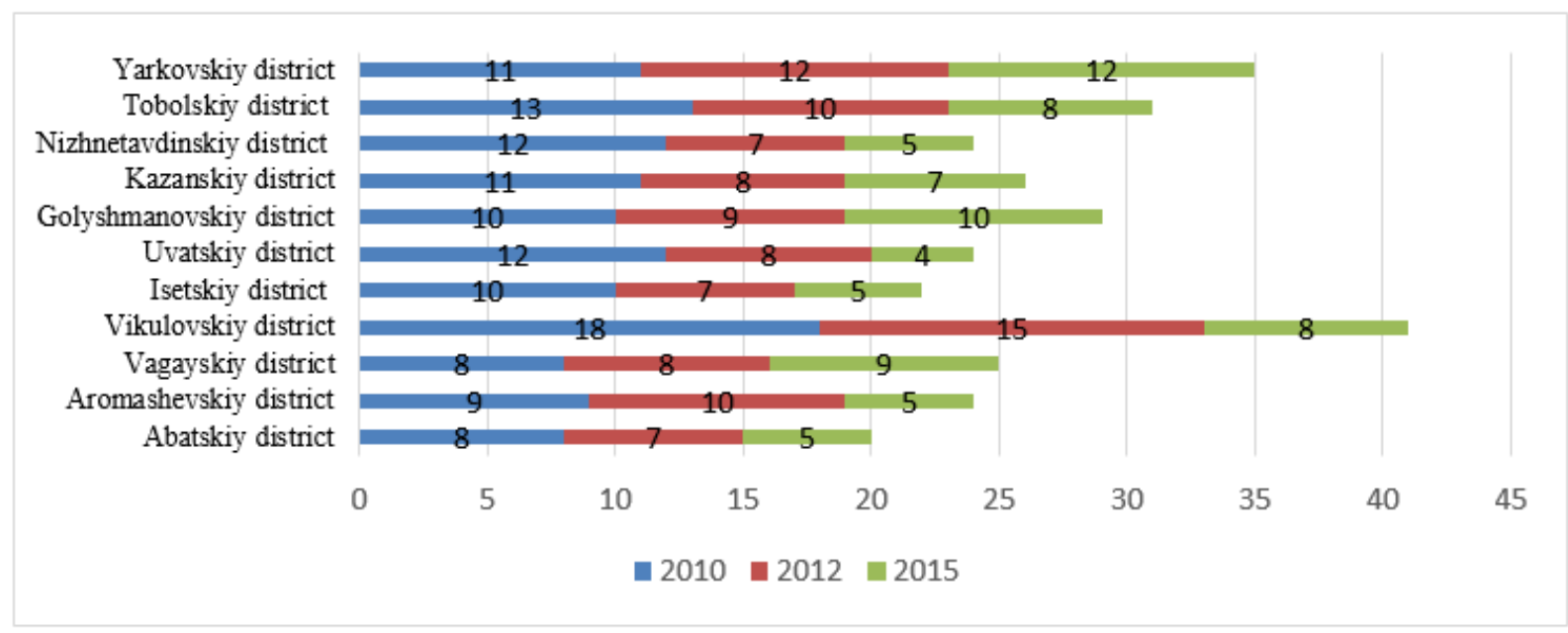

Fig. 3. Dynamics of change in the number of existing agricultural enterprises in the south of Tyumen region [6]

The system of the agro-industrial complex of the region (without autonomous okrugs) looks as follows.

This resulted in a decrease in the number of operating agricultural enterprises (see Fig.2). On average, from 2010 to 2015 the number of agricultural enterprises decreased by $36 \%$. The positive dynamics in the number of operating enterprises has been observed only in three districts: Yarkovskiy, Golyshmanovskiy and Vagayskiy.

These areas are also leaders in the growth of total income, average monthly income per inhabitant and the number of employees. Figure 3 presents a generalized analysis, which was carried out by the authors on the basis of data from three years - 2010, 2012 and 2015.

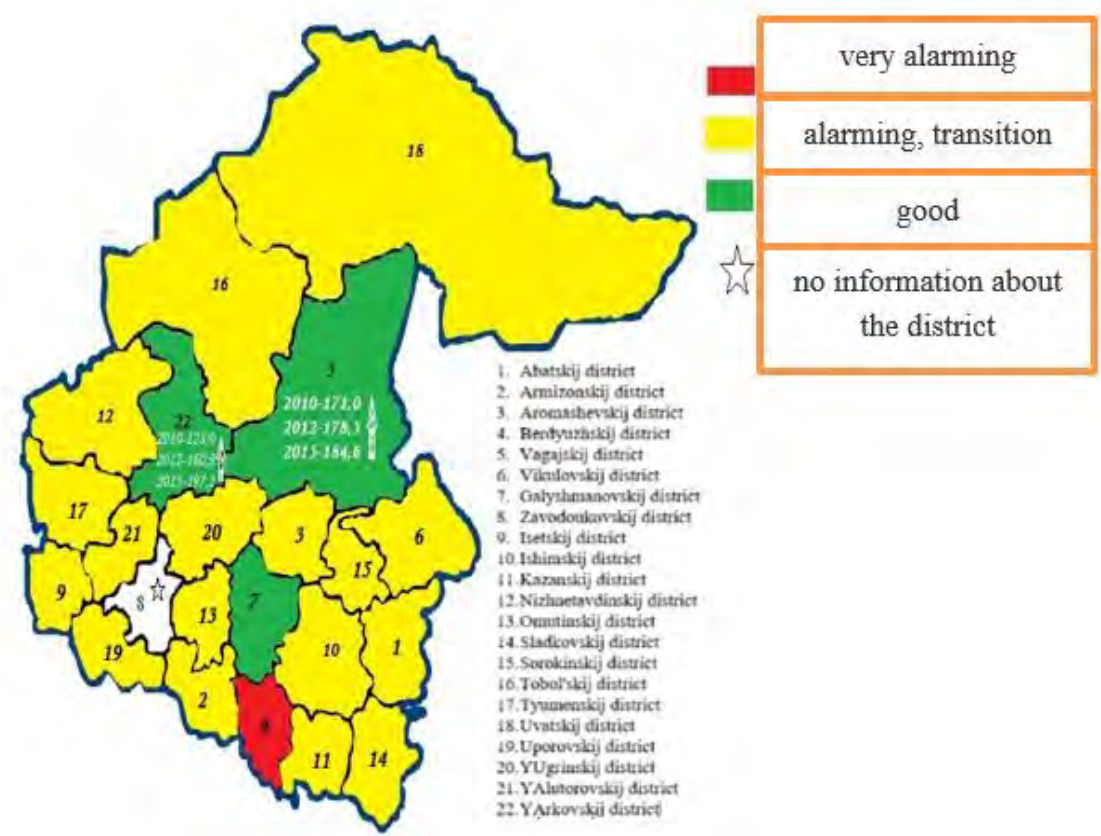

Fig. 4. Indicator map of the economic condition of the south of Tyumen region [3] 
At the same time, in most rural areas of the region, which have successfully developed agricultural production until recently, the number of workers has decreased dramatically (see Fig.4) [3, 4, 16,]. Poverty has become the main problem of the village, causing the marginalization of the rural population. People move to the cities, still aggravating the difficult socio-demographic situation in the village, caused by the lack of work and means for life $[6,7,9,11]$.

For a more detailed study of the socio-economic state of the areas in the south of Tyumen region, an analysis of the population on the following map is shown (Fig. 5).

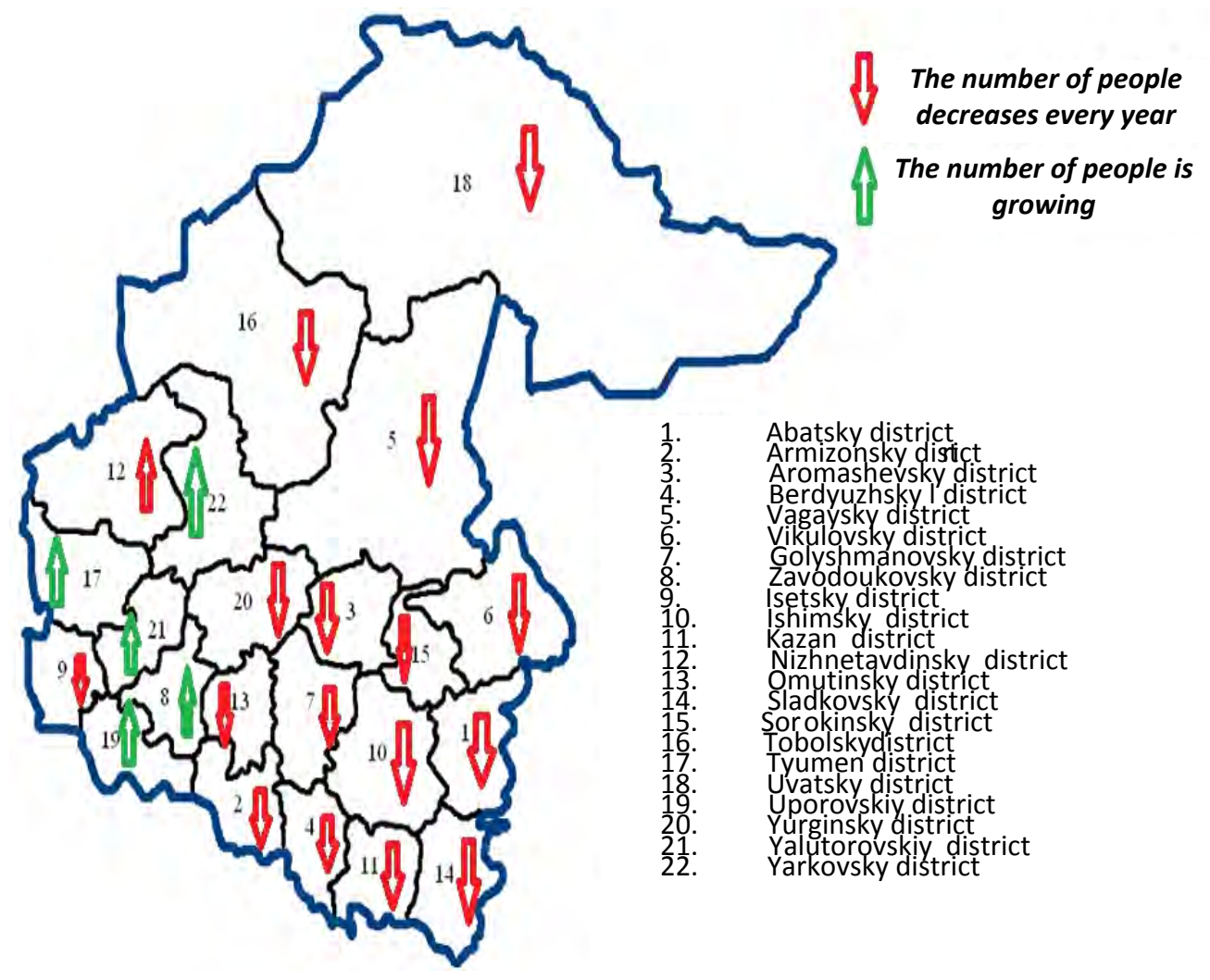

Fig. 5. Map of indicators indicators of the population of the south of the Tyumen region * developed by the authors themselves

On the population indicator map, an alarming state is observed in most areas, only in five of them (Yarkovsky, Tyumen, Yalutorovsk, Uporovsky and Zavodoukovsky districts) there is an increase in the population. The remaining territories are in a state of demographic crisis.

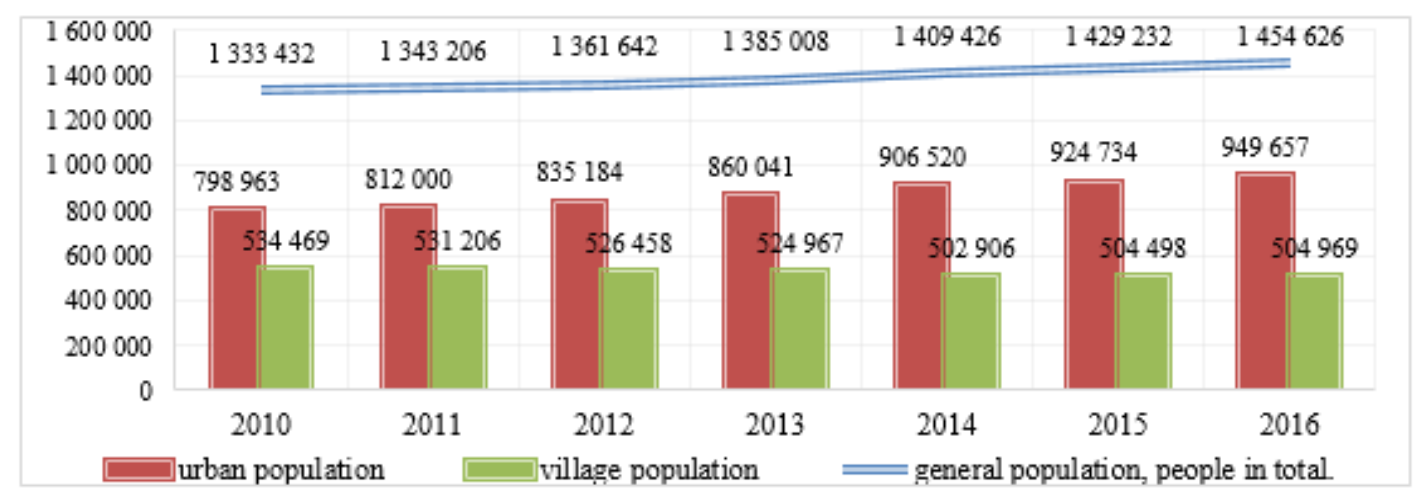

Fig. 6. Number of permanent population of Tyumen region (without Autonomous districts), people [6] 
For more than ten years, a decrease in the number of people employed in the agricultural production (see Fig.7) has been observed, as well as a growth of dependency among those who remain, and the lack of interest in peasant and farm labor.

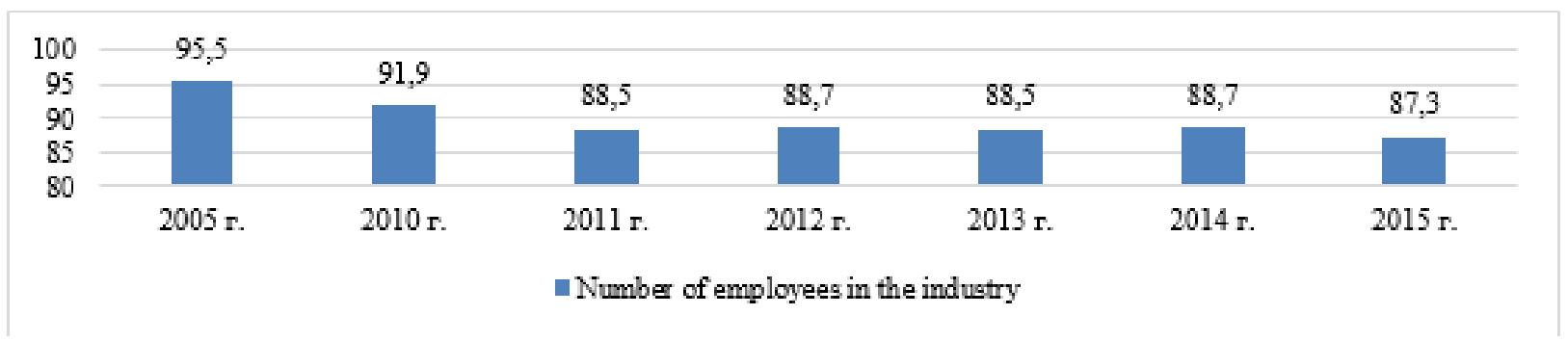

Fig. 7. Number of employees in agriculture in Tyumen region, thousand people [6]

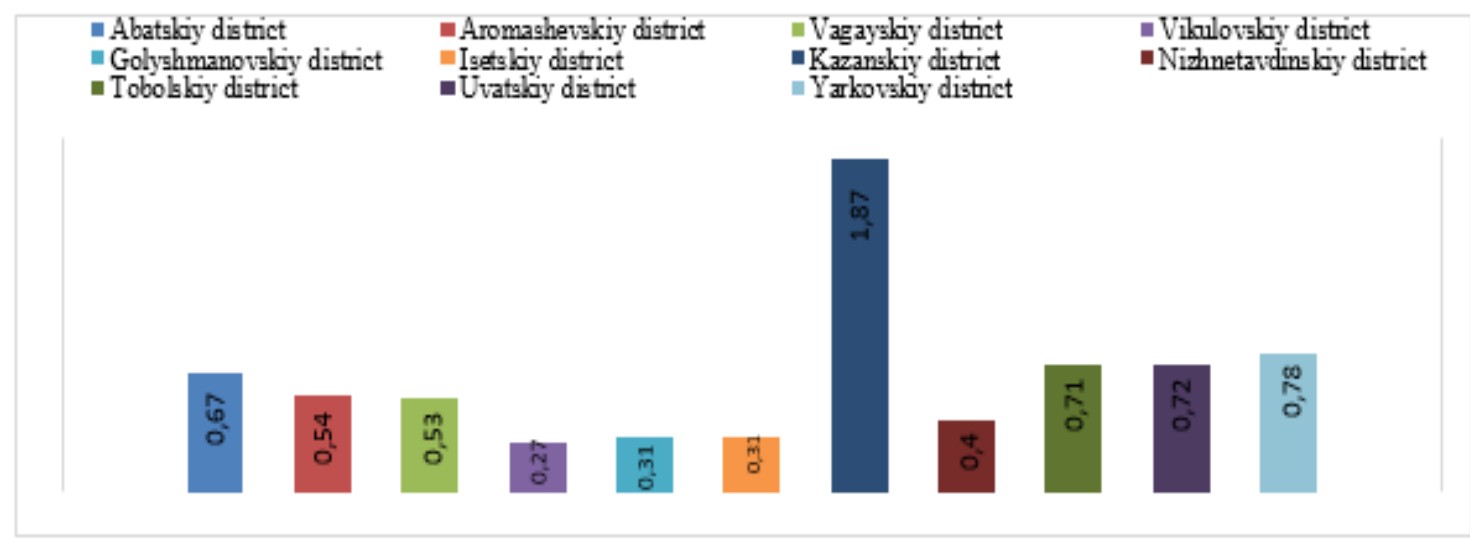

Fig. 8. The level of registered unemployment in agricultural areas of Tyumen region [6]

In rural areas, the level of registered unemployment, for example, as of 01.05 .2016 , increased by 0.02 percentage points compared to the same period of the last year (see Fig. 6 ). The coefficient of tension on the labor market was 0.4 people per 1 declared vacancy with 0.5 people as of the same date in 2015. The most difficult situation was in Kazanskiy and Yarkovskiy districts of the region.

At the same time, in Tyumen region there are state programs to support rural areas; their main goal is to create a stable working agro-industrial complex for 2013-2020. As a result of their implementation, it is expected to expand the range of agricultural products of high quality, the introduction of innovative technologies, the creation of sustainable rural cooperation, the effective development and rational use of agricultural land, the creation of new jobs. But based on the results of the analysis conducted by the authors, the state programs to support rural areas, farming, and agricultural development in the region have not given the expected result. Despite the presence of anti-crisis measures and support of agribusiness by the government of Tyumen region, progress in the development and increase of agricultural production volume is not observed, and in some categories there is a decline in production, which is evidence of the lack of measures taken or not fully implemented. This naturally affects the growth of prices for agricultural products sold.
Thus, today there is a situation in which the agricultural sector of Tyumen region does not cope with the task of providing food to the population. Clustering of Tyumen region economy, the presence of the basic economic cluster (fuel and energy cluster) forms the external orientation of production and is less dependent on the socio-economic situation within the region. At the same time, such sector of the region's economy as agribusiness, not being the basic one, focuses its activities mainly on the needs of the domestic consumer.

Under these circumstances, the region is faced with the issue of food procurement orientation. There are two approaches to the solution of the problem of providing the population with food products:

1. development of import of food products from nearby regions of Russia;

2. development of local agricultural production.

The first approach is based on the existence of strong, long-established commodity relations between the subjects of the Russian Federation. However, in this case, the solution of problems related to the provision of food to the population will lead to aggravation of social problems related to employment of the population, primarily rural settlements of the Tyumen region south. The lack of jobs in rural areas will 
lead to an even greater outflow of the population to major cities.

The second approach allows avoiding negative consequences, but requires a larger financial investment. This is due to the creation of new enterprises (reconstruction and modernization of old enterprises) (according to the regional program quite a large investment is allocated in this area), with the involvement of educational institutions in the cluster to create an interconnected and mutually reinforcing "production - processing - implementation of the finished product" cycle with scientific-methodical and consulting support of the process. The expansion of the agricultural cluster is also proposed through the involvement in the turnover, in particular, the Kurgan region, that will use the potential of both areas to achieve their goals on mutually beneficial terms. Kurgan region has a high potential for the development of agriculture; the most promising areas for the development of cooperation in this area are Shatrovskiy, Shadrinskiy, Belozerskiy, Ketovskiy, Vargashinskiy districts, with three advantages of placing agricultural production in them:

1. availability of land plots suitable for farming;

2. availability of labor (work) resources from the local population;

3. transport accessibility (proximity to the regional center), availability of highways.

The convergence of the two regions - Tyumen and Kurgan regions - their closer cooperation in the economic, social, educational and other spheres will be beneficial to both sides. The obvious advantages include:

1. increase in labor migration flows;

2. integration of academic space through cooperation.

\section{CONCLUSION}

Thus, expanding cooperation and taking into account the mutually beneficial advantages, the cluster method of agribusiness development of two regions - Tyumen and Kurgan - with the involvement of universities of agricultural profile with their research projects aimed at innovative development of agro-industrial complex, will bring a new level of the socio-economic situation of the territories, regions, as well as ensure food security in the region and solve the problem of providing the population with affordable and highquality agricultural products. This will also contribute to reducing unemployment in the region and the growing of the rural population prosperity.

\section{References}

[1] The concept of sustainable development of rural areas of the Russian Federation for the period up to 2020, Retrieved from: http://docs.cntd.ru/document/902250089 last accessed 2018/05/05

[2] Regions of Russia. Socio-economic indicators, Retrieved from: http://www.gks.ru/wps/wcm/connect/rosstat_main/rosstat/ru/statistics/pu blications/catalog/doc_1138623506156 last accessed 2018/05/06

[3] L.B. Osipova, E.A. Kolesnik, and O.M. Goreva, "Infrastructural support for the development of the youth segment of the regional labor market. Economic and social changes: facts, trends, forecast,", vol. 11 (2), pp.175-191, 2018, DOI: 10.15838/esc.2018.2.56.12.

[4] N.Chistyakova, T Gromova, M. Soloviev and A. Braychenko, "Influence of social-economic institutions on innovative environment development: Russian case study,"15 June 2016, DOI: https://doi.org/10.1051/shsconf/20162801121.

[5] A.N. Dmitrievskii, A.M. Mastepanov and V.V. Bushuev, "Resourceinnovative strategy of Russia's economic development,". Herald of the Russian Academy of Science, vol. 84 (5), pp. 329-334, 2014.

[6] L.M. Gaisina, R.N.Bakhtizin, I.M. Mikhaylovskaya, N.G. Khairullina and M.L. Belonozhko, "Sociological evaluation of effectiveness of labor workers' behavior,”. Biosciences Biotechnology Research Asia, vol. 12 (3), pp. 3091-3100, 2015.

[7] T. Gerashchenkova, "Theoretic-methodological approaches to determine the content and classification of innovation-investment development strategies," 15 June https://doi.org/10.1051/shsconf/20162801042.

[8] Y.D. Granin, "Globalization and national forms of global strategies", Herald of the Russian Academy of Science, vol. 84 (2), pp. 135-141, 2014.

[9] L.L.Pavlova, E.A. Kolesnik and P.Y. Petrov, "Management efficiency of public finances as a basis budget system development of the Russian Federation," European Proceedings of Social and Behavioural Sciences, vol. 35, pp.1033-1041, 2018.

[10] N.V. Stepanova and A. A. Razumakov," The effect of doping with copper and aluminum on structure, mechanical and friction properties of steel" , vol. 1, pp. 240-242, 2013 [The 8 international forums on strategic technologies (IFOST 2013), 2018]

[11] The report on the main directions of increase of efficiency of expenses of the Federal budget (2015), Retrieved from http: http://minfin.ru/ common/upload/library/2015/ 07/main/ doklad_ob_osnovnykh_napravleniyakh_povysheniya_effektivnosti_rask hodov_federalnogo_budzheta.pdf last accessed 2018/05/03.

[12] N. Zavyalova, "Dataset for an analysis of communicative aspects of finance,". Data in Brief, April 2017, Vol.11, pp. 197-203, DOI: http://dx.doi.org/10.1016/j.ribaf.2016.07.039. 